\title{
Impact of Diets Containing Plant Raw Materials as Fish Meal and Fish Oil Replacement on Rainbow Trout (Oncorhynchus mykiss), Gilthead Sea Bream (Sparus aurata), and Common Carp (Cyprinus carpio) Freshness
}

\author{
Grigorakis Kriton (D), ${ }^{1}$ Kogiannou Dimitra, ${ }^{1}$ Genevieve Corraze, ${ }^{2}$ Pérez-Sánchez Jaume, ${ }^{3}$ \\ Agnes Adorjan, ${ }^{4}$ and J. Sándor Zsuzsanna ${ }^{4}$ \\ ${ }^{1}$ Institute of Marine Biology, Biotechnology \& Aquaculture, Hellenic Centre for Marine Research, Ag. Kosmas Hellinikon, \\ 16777 Athens, Greece \\ ${ }^{2}$ INRA, UMR 1419 "Nutrition Métabolisme Aquaculture”, Aquapôle, 64310 Saint-Pée-sur-Nivelle, France \\ ${ }^{3}$ Nutrigenomics and Fish Growth Endocrinology Group, Institute of Aquaculture Torre de la Sal, Ribera de Cabanes, Castellón, Spain \\ ${ }^{4}$ National Agricultural Research and Innovation Centre, Research Institute for Fisheries and Aquaculture (HAKI), Szarvas, Hungary \\ Correspondence should be addressed to Grigorakis Kriton; kgrigo@hcmr.gr
}

Received 12 September 2017; Revised 24 November 2017; Accepted 11 December 2017; Published 15 February 2018

Academic Editor: Chunhong Yuan

Copyright (C) 2018 Grigorakis Kriton et al. This is an open access article distributed under the Creative Commons Attribution License, which permits unrestricted use, distribution, and reproduction in any medium, provided the original work is properly cited.

\begin{abstract}
The present study aimed to evaluate whether the total or high substitution of fish meal (FM) and fish oil (FO) by sustainable plant raw materials (plant meal and oils) in long-term feeding for rainbow trout, gilthead sea bream, and common carp can result in spoilage alterations during ice storage. These three species were fed throughout their whole rearing cycle with plant-based diets and compared to counterparts that received FM/FO-based diets or commercial-like diets. Sensory QIM schemes adopted for these species and ATP breakdown products ( $K$-value and components) were used to evaluate the freshness. Sensory acceptability of 14 , 15 , and 12 days was found for rainbow trout, gilthead sea bream, and common carp, respectively. This corresponded to $K$-values of approximately $80 \%, 35 \%$, and $65 \%$ for rainbow trout, gilthead sea bream, and common carp, respectively. No major effect of dietary history on postmortem shelf life was shown for gilthead sea bream and common carp; neither sensory-perceived nor chemical freshness showed diet-related differences. Rainbow trout fed with the plant-based diet exhibited slightly worse sensory freshness than fish fed with FM/FO-based diets, at the end of shelf life. These findings imply that FM and FO can be successfully substituted without major impacts on shelf life of fish.
\end{abstract}

\section{Introduction}

In recent years, the aquaculture feed industry has attempted to substitute fish meal (FM) and fish oil (FO) in the feeds with sustainably produced plant raw materials $[1,2]$. The need for this substitution was mainly the result of the continuous growth of aquaculture, the limited FM and FO resources, and the increasing global needs in seafood $[3,4]$.

Rainbow trout (Oncorhynchus mykiss) is one of the most important farmed fish species with its total world production exceeding 800,000 tonnes annually in the last years [5]. The gilthead sea bream Sparus aurata is an important marine species with major importance in the Mediterranean mariculture as its total annual production reaches 160,000 tonnes [6]. The common carp Cyprinus carpio is a worldwide distributed freshwater species with great commercial significance since its aquaculture production exceeded 4 million tonnes in 2014 [7]. Considering the production numbers and their importance in the aquaculture, these three species are of major interest and they are also major consumers of feeds. Thus, the substitution of FM and FO in their diets has been among the priorities in the sector.

There is plenty of evidence that dietary FM and FO replacement in fish can significantly alter the final product 
quality. Besides the obvious effects in fillet fatty acids, also the total volatile compounds and sensory properties, namely, the appearance, odour, flavour, and texture of fillet, can be affected [8-14]. In particular, in cases of sweet-water fish species, the recorded impacts included reduction of the total amount of aldehydes and alcohols concomitant to fillet n-3 fatty acids reduction, increase of n- 6 derived aldehydes, and related sensory-perceived "off-flavour" for plant oil fed fish $[9,10,15]$. Minor changes in individual volatile compounds have been mentioned for gilthead sea bream $[12,13]$ as well as an increased perception of fattiness in fish that received plant-based diets [13].

Being a highly perishable food, fish can have their shelf life affected by numerous factors besides the obvious that is the storage temperature [16]. Among them, factors related to the nutritional status of fish can impact the postmortem changes that the fish undergoes. Thus, season-related metabolic differences, lipid depots, and starvation seem to have an effect on fish spoilage patterns [17-20]. In a further step, there are some indications that incorporation of dietary plant raw materials can have an effect on the postmortem quality of farmed fish (i.e., on their spoilage pattern during storage) [21]. For instance, Cabral et al. [22] observed differences in the perceived freshness in cooked fillets of Senegalese sole in fish fed with an FM diet and fish fed with a diet with $75 \%$ of FM replaced by plant meals. In rainbow trout that received different plant oils as substitutes to FO, lower lipid peroxidation was observed when compared to FO fed fish in 6- and 9-day refrigerated fillets, but no sensory difference was recorded [9].

Although there is adequate literature examining the freshness of ice-stored rainbow trout [23, 24], gilthead sea bream [25-28], and common carp [24], there are few data of the feeding effects on fish freshness for these species. In the past, there has been some research in regard to partial FM substitution and its effects on rainbow trout and gilthead sea bream's postmortem quality $[13,29,30]$. However, no data is available for high and concomitant substitution of FM and FO. Within these frames, the aim of the present study was to evaluate whether the high replacement of FM and FO by sustainable plant raw materials (plant proteins (PP) and vegetable oils (VOs)) in rainbow trout, gilthead sea bream, and common carp can result in alterations in postmortem spoilage during ice storage.

Since the rainbow trout and the common carp are able to elongate and desaturate C18 fatty acids to synthesize 20:5 $\omega 3$ (EPA) and 22:6w3 (DHA) [31], a total replacement of FM/FO was chosen to be tested for these two species. On the other hand, this was not the case for gilthead sea bream, since marine species lack this capacity to synthesize polyunsaturated fatty acids; a maximum replacement of FM/FO was tested, with those two raw materials being lowered down to a contributing level of less than $10 \%$ in the diet.

\section{Experimental}

\subsection{Diets, Rearing, and Sampling}

2.1.1. Rainbow Trout. Three experimental diets were formulated and produced as extruded diets by the Institut National de la Recherche Agronomique (INRA): a marine diet (M) based on FM and FO, a commercial-like diet (C) containing an equal mixture $(50 / 50 \%)$ of marine and plant ingredients (FM-FO), and a totally plant-based diet (V) (100\% plant protein (PP) and vegetable oils (VOs)) devoid of any marine resource. The diet formulations were chosen to satisfy the nutritional requirements of trout according to NRC [32]. Diet $\mathrm{V}$ was supplemented with lysine, methionine, soy lecithin, and calcium phosphate. An attractant mix (glycine: 13, alanine: 13 , betaine: 20 , taurine: 20 , and glucosamine: $330 \mathrm{~g} \mathrm{~kg}^{-1}$ ) was also added in this diet in order to counteract possible negative effects of vegetable ingredients on feed intake of trout. The diets formulations and their proximate composition are given in Table 1.

Rainbow trout of the same origin were reared in INRA's experimental facilities from the 1st feeding onwards and fed with the 3 experimental diets. At the beginning of the trial, approximately 3700 rainbow trout fry, mean weight $135 \pm$ $1 \mathrm{mg}$, were split into three groups (4 replicates per group) and reared at the INRA fish farm of Lées-Athas supplied by spring water at a constant temperature (around $7^{\circ} \mathrm{C}$ ) and under natural photoperiod conditions for 7 months. Fish were fed by hand until apparent satiation ( 8 meals a day at first feeding; then, the daily meal number was gradually reduced as fish weight increased). When fish reached $10 \mathrm{~g}$ (7-month feeding), they were transferred to another INRA experimental facility in Donzacq supplied by spring water at a stable temperature around $18^{\circ} \mathrm{C}$ and oxygen content at $9 \mathrm{mg} \mathrm{L}^{-1}$ and reared under natural photoperiod conditions. Fish were distributed in $1000 \mathrm{~L}$ tanks in triplicate groups of 150 fish per dietary treatment and fed by hand to apparent satiation ( 2 meals a day) with the 3 experimental diets until they reached the commercial size of $1.1-1.5 \mathrm{~kg}$ (26-month feeding in total).

At the end of the trial, fish were slaughtered by ice-killing and bleeding method, packed with ice $\left(0^{\circ} \mathrm{C}\right)$, and shipped to HCMR, Athens. Fish were kept in ice and melting ice was replaced daily with fresh one and excess water was drained.

2.1.2. Gilthead Sea Bream. Four isoproteic and isolipidic plant protein-based diets (1.9, 3, and $4.5 \mathrm{~mm}$ extruded feeds) were formulated and delivered by BioMar (Denmark). FM was included at $230 \mathrm{~g} \mathrm{~kg}^{-1}$ in the D1 diet (control) and at $30 \mathrm{~g} \mathrm{~kg}^{-1}$ in the other three experimental diets (D2, D3, and D4). Fish hydrolysate (CPSP) was added at $2 \mathrm{~g} \mathrm{~kg}^{-1}$ in all diets. The added oil was either FO (D1 diet) or a blend of VOs (1:1 ratio of rapeseed oil : palm oil) replacing 58\% (D2 diet) and $84 \%$ (D3 and D4 diets) FO. A commercial butyrate preparation (NOREL, 70-BP) was added to the D4 diet at $4 \mathrm{~g} \mathrm{~kg}^{-1}$. All diets contained histidine $\left(1.4 \mathrm{~g} \mathrm{~kg}^{-1}\right)$, antioxidants $\left(0.45 \mathrm{~g} \mathrm{~kg}^{-1}\right)$, and a mineral-vitamin mix $\left(5 \mathrm{~g} \mathrm{~kg}^{-1}\right)$. Lysine, methionine, choline, lecithin, and monocalcium phosphate were balanced in D2, D3, and D4 diets to the values of the control diet (Table 2).

Gilthead sea bream of Atlantic origin (Ferme Marine de Douhet, France) were reared in the experimental facilities of the Institute of Aquaculture Torre de la Sal (IATS, Spain). Fish with an initial weight of 13-16 g were distributed in $2500 \mathrm{~L}$ tanks in triplicate groups of 180 fish each. Oxygen content of 
TABLE 1: Formulations and proximate compositions of the rainbow trout experimental diets fed from $10 \mathrm{~g}$ to $1.1-1.5 \mathrm{~kg}$.

\begin{tabular}{|c|c|c|c|}
\hline Ingredients $\left(\mathrm{g} \mathrm{kg}^{-1}\right.$ feed $)$ & $\mathrm{M}$ & $\mathrm{C}$ & $\mathrm{V}$ \\
\hline Fish meal & 543.2 & 300.0 & 0 \\
\hline Corn gluten & 0 & 102.5 & 180.0 \\
\hline Wheat gluten & 0 & 50.0 & 120.7 \\
\hline Soybean meal 48 & 0 & 63.0 & 43.0 \\
\hline Soy protein concentrate & 0 & 35.0 & 181.0 \\
\hline White lupin & 0 & 64.7 & 4.97 \\
\hline Dehulled pea & 0 & 69.5 & 23.8 \\
\hline Rapeseed meal & 0 & 63.1 & 98.5 \\
\hline Extruded whole wheat & 301.0 & 71.7 & 27.9 \\
\hline Fish oil & 135.8 & 80.0 & 0 \\
\hline Rapeseed oil & 0 & 80.0 & 73.0 \\
\hline Linseed oil & 0 & 0 & 73.7 \\
\hline Palm oil & 0 & 0 & 30.0 \\
\hline Soy lecithin & 0 & 0 & 20.0 \\
\hline L-Lysine & 0 & 0.05 & 15.0 \\
\hline L-Methionine & 0 & 0 & 3.00 \\
\hline $\mathrm{CaHPO}_{4} \cdot 2 \mathrm{H}_{2} \mathrm{O}(18 \% \mathrm{P})$ & 0 & 0 & 25.8 \\
\hline Attractant mix & 0 & 0 & 15.0 \\
\hline Min. premix & 10.0 & 10.0 & 10.0 \\
\hline Vit. premix & 10.0 & 10.0 & 10.0 \\
\hline \multicolumn{4}{|l|}{ Proximate composition } \\
\hline $\mathrm{DM}\left(\mathrm{g} \mathrm{kg}^{-1}\right)$ & 962.6 & 960.1 & 963.1 \\
\hline Protein $\left(\mathrm{g} \mathrm{kg}^{-1}\right)$ & 439.4 & 463.9 & 461.4 \\
\hline Fat $\left(\mathrm{g} \mathrm{kg}^{-1}\right)$ & 218.3 & 242.2 & 250.0 \\
\hline Energy $\left(\mathrm{kJ} \mathrm{g}^{-1} \mathrm{DM}\right)$ & 24.51 & 23.84 & 25.32 \\
\hline Ash (\% DM) & 78.9 & 61.1 & 56.5 \\
\hline \multicolumn{4}{|l|}{$\begin{array}{l}\text { Fatty acid composition } \\
\left(\mathrm{g} \mathrm{kg}^{-1} \text { total FA) }\right.\end{array}$} \\
\hline $16: 0$ & 173 & 119 & 147 \\
\hline $18: 2 \omega 6$ & 281 & 127 & 219 \\
\hline $18: 3 \omega 3$ & 8.4 & 43.0 & 219 \\
\hline $20: 4 \omega 6$ & 7.40 & 4.2 & 0 \\
\hline $20: 5 \omega 3$ & 146 & 79 & 0 \\
\hline $22: 6 \omega 3$ & 99 & 52 & 0 \\
\hline Total SFA ${ }^{1}$ & 286 & 193 & 185 \\
\hline Total MUFA ${ }^{2}$ & 295 & 429 & 372 \\
\hline Total n-6 & 91 & 161 & 220 \\
\hline Total n-3 & 293 & 204 & 219 \\
\hline
\end{tabular}

${ }^{1}$ SFA: saturated fatty acids; ${ }^{2}$ MUFA: monounsaturated fatty acids.

outlet water remained higher than $75 \%$ saturation, and daylength and water temperature followed the natural changes at the respective latitude $\left(40^{\circ} 5^{\prime} \mathrm{N} ; 0^{\circ} 10^{\prime} \mathrm{E}\right)$ during the feeding trial that lasted eight months (May 2013 to December 2013) until fish reached commercial sizes (for details on growth performance, see Benedito-Palos et al., 2016 [33]).

At the end of the trial, fish were slaughtered according to the EFSA-approved [34] custom commercial method (icekilling), packed with ice, and shipped to HCMR, Athens.
Fish were packed with ice in Styrofoam boxes and remained refrigerated $\left(0^{\circ} \mathrm{C}\right)$ throughout postmortem storage. Melting ice was replaced daily with a fresh quantity and excess water was drained.

2.1.3. Common Carp. Two groups of semi-intensive supplementary feeds were formulated for rearing common carp in monoculture ponds of intensive natural food production. One group of feeds contained plant meals (PM) and VO 
TABLE 2: Formulations and proximate compositions of the gilthead sea bream experimental diets.

\begin{tabular}{|c|c|c|c|c|}
\hline Ingredients ( $\mathrm{g} \mathrm{kg}^{-1}$ feed $)$ & D1 & $\mathrm{D} 2$ & D3 & $\mathrm{D} 4$ \\
\hline Fish meal & 230 & 30 & 30 & 30 \\
\hline Fish hydrolysate (CPSP) & 20 & 20 & 20 & 20 \\
\hline Soya protein & 160 & 250 & 250 & 250 \\
\hline Corn gluten & 150 & 250 & 250 & 250 \\
\hline Wheat gluten & 40.0 & 73.0 & 73.0 & 73.0 \\
\hline Rapeseed cake & 120 & 97.0 & 99.0 & 99.0 \\
\hline Wheat & 110.8 & 68.0 & 66.4 & 62.4 \\
\hline Fish oil & 156 & 65.6 & 25.0 & 25.0 \\
\hline Rapeseed oil & 0 & 44.0 & 65.0 & 65.0 \\
\hline Palm olein & 0 & 44.0 & 65.0 & 65.0 \\
\hline Monocalcium phosphate & 3.03 & 20.97 & 20.97 & 20.97 \\
\hline Histidine & 1.36 & 1.36 & 1.36 & 1.36 \\
\hline Mineral-vitamin $\operatorname{mix}^{\mathrm{a}}$ & 5.00 & 5.00 & 5.00 & 5.00 \\
\hline Cholesterol & 1.13 & 1.13 & 1.13 & 1.13 \\
\hline Amino acid and micronutrient mix ${ }^{\mathrm{b}}$ & 2.00 & 29.2 & 27.4 & 27.4 \\
\hline Antioxidants & 0.45 & 0.45 & 0.45 & 0.45 \\
\hline BP-70 & 0 & 0 & 0 & 4.00 \\
\hline \multicolumn{5}{|l|}{ Proximate composition } \\
\hline $\mathrm{DM}\left(\mathrm{g} \mathrm{kg}^{-1}\right)$ & 916.5 & 917.9 & 918.0 & 923.4 \\
\hline Protein $\left(\mathrm{g} \mathrm{kg}^{-1}\right)$ & 454.8 & 467.3 & 461.2 & 460.3 \\
\hline Fat $\left(\mathrm{g} \mathrm{kg}^{-1}\right)$ & 198.0 & 195.6 & 201.3 & 194.0 \\
\hline Energy $\left(\mathrm{kJ} \mathrm{g}^{-1} \mathrm{DM}\right)$ & 22.00 & 22.26 & 22.25 & 22.19 \\
\hline Ash (\% DM) & 66.9 & 60.6 & 60.6 & 64.6 \\
\hline \multicolumn{5}{|l|}{$\begin{array}{l}\text { Fatty acid composition } \\
\left(\mathrm{g} \mathrm{kg}^{-1} \text { total FA) }\right.\end{array}$} \\
\hline $16: 0$ & 166 & 135 & 117 & 119 \\
\hline $18: 2 \omega 6$ & 69.2 & 178 & 198 & 198 \\
\hline $18: 3 \omega 3$ & 16.8 & 37.9 & 56.2 & 57.7 \\
\hline $20: 4 \omega 6$ & 8.40 & 4.10 & 1.90 & 1.80 \\
\hline $20: 5 \omega 3$ & 131 & 63.2 & 29.6 & 28.9 \\
\hline $22: 6 \omega 3$ & 91.6 & 43.9 & 21.1 & 20.7 \\
\hline Total SFA & 278 & 246 & 231 & 234 \\
\hline Total MUFA & 253 & 345 & 411 & 401 \\
\hline Total n-6 & 224 & 292 & 303 & 311 \\
\hline Total n-3 & 245 & 117 & 551 & 540 \\
\hline
\end{tabular}

${ }^{\mathrm{a}}$ The following is supplied ( $\mathrm{g} \mathrm{kg}^{-1} \mathrm{mix}$, except as noted): calcium 689 , sodium 108, iron 3, manganese 1, zinc 1, cobalt $2 \mathrm{mg}$, iodine $2 \mathrm{mg}$, selenium $20 \mathrm{mg}$, molybdenum $32 \mathrm{mg}$, retinyl acetate 1, DL-cholecalciferol 2.6, DL- $\alpha$-tocopheryl acetate 28 , menadione sodium bisulphite 2, ascorbic acid 16, thiamin 0.6 , riboflavin 1.7, pyridoxine 1.2, vitamin B12 $50 \mathrm{mg}$, nicotinic acid 5, pantothenic acid 3.6, folic acid 0.6, and biotin $50 \mathrm{mg}$. ${ }^{\mathrm{b}}$ Containing methionine, lysine, choline, and lecithin.

(with no FM or FO), and the other group of feeds contained moderate levels of both FM and FO. The pairs of the plantbased and marine-based feeds were formulated to contain practically equal crude protein levels. Feeds were manufactured by extrusion pelleting and crumbling, with pellet sizes being $2.2-3.0$ in early stages, $>3 \mathrm{~mm}$ in juvenile size, and $5 \mathrm{~mm}$ in adult size. The analytic formulation and composition of diets are shown in Table 3. As control feed, cereals (mainly winter wheat) were used following the traditional feeding technology in Central Europe.
The feed trial took place in Szarvas (Hungary) in the experimental ponds of HAKI together with SME (SmallMedium Enterprise) partner, KARAS. Common carp fry of the scaly variety were stocked into six earthen ponds of about $1700 \mathrm{~m}^{2}$ each, previously fertilised with cow manure (3t/ha) at a density of 20,000 fish/ha. Fish were fed with either FM/FO (F diet), PM/VO (V diet), or ground wheat ( $\mathrm{C}$ diet) according to their parental feeding regimes, in duplicate groups. Additionally, the ponds were manured twice (1 and 1.7 tonnes/ha) during the nursing period. Fish samples (about 
TABLE 3: Formulations and proximate compositions of carp feeds containing plant ingredients $(\mathrm{P})$ and feeds containing low FM and FO (F).

\begin{tabular}{|c|c|c|c|c|}
\hline \multirow{2}{*}{$\begin{array}{l}\text { Feed name/formula code } \\
\text { Ingredients }\end{array}$} & \multicolumn{2}{|c|}{$\begin{array}{l}\text { Juveniles/adults } \\
\text { (V diet) }\end{array}$} & \multicolumn{2}{|c|}{$\begin{array}{l}\text { Juveniles/adults } \\
\text { (F diet) }\end{array}$} \\
\hline & 2014 & 2015 & 2014 & 2015 \\
\hline Fishmeal (60\% protein) & 0 & 0 & 160.0 & 140.0 \\
\hline Winter wheat meal & 89.0 & 165.0 & 100.8 & 205.0 \\
\hline Maize & 270.0 & 275.0 & 40.3 & 65.0 \\
\hline Full-fat soya & 90.0 & 95.0 & 307.3 & 275 \\
\hline Soybean meal ( $46 \%$ protein) & 383.0 & 295.0 & 40.3 & 65.0 \\
\hline Blood meal & 80.0 & 80.0 & 50.0 & 50.0 \\
\hline Yeast, feed grade & 50.0 & 50.0 & 50.0 & 50.0 \\
\hline Vit.-min. mix & 20.0 & 20.0 & 20.0 & 20.0 \\
\hline Fish oil & 0 & 0 & 18.0 & 20.0 \\
\hline Linseed oil & 18.0 & 20.0 & 0 & 0 \\
\hline \multicolumn{5}{|l|}{ Proximate composition } \\
\hline Dry matter $\left(\mathrm{g} \mathrm{kg}^{-1}\right)$ & 917.1 & 925.0 & 918.4 & 918.6 \\
\hline Crude protein $\left(\mathrm{g} \mathrm{kg}^{-1}\right)$ & 317.2 & 295.7 & 327.0 & 301.8 \\
\hline Crude fat $\left(\mathrm{g} \mathrm{kg}^{-1}\right)$ & 59.2 & 74.3 & 62.7 & 73.8 \\
\hline Energy (KJ/g DM) & 18.2 & 18.3 & 18.1 & 18.0 \\
\hline Crude fibre $\left(\mathrm{g} \mathrm{kg}^{-1}\right)$ & 42.3 & 33.6 & 61.3 & 28.7 \\
\hline Crude ash $\left(\mathrm{g} \mathrm{kg}^{-1}\right)$ & 23.2 & 42.1 & 22.4 & 59.6 \\
\hline \multicolumn{5}{|l|}{$\begin{array}{l}\text { Fatty acid composition } \\
\left(\mathrm{g} \mathrm{kg}^{-1} \text { total FA) }\right.\end{array}$} \\
\hline $16: 0$ & 112.3 & 112.9 & 150.3 & 145.9 \\
\hline $18: 2 \omega 6$ & 382.8 & 401.6 & 287.3 & 312.9 \\
\hline $18: 3 \omega 3$ & 184.3 & 187.5 & 40.0 & 60.4 \\
\hline $20: 4 \omega 6$ & 0.90 & 0.70 & 5.90 & 5.30 \\
\hline $20: 5 \omega 3$ & 2.10 & 0.70 & 29.7 & 24.5 \\
\hline $22: 6 \omega 3$ & 4.50 & 1.90 & 65.0 & 59.5 \\
\hline Total SFA & 188.2 & 164.5 & 256.0 & 216.3 \\
\hline Total MUFA & 226.0 & 238.0 & 274.0 & 283.0 \\
\hline Total n-6 & 373.4 & 402.7 & 301.1 & 326.9 \\
\hline Total n-3 & 184.3 & 190.1 & 144.6 & 153.6 \\
\hline
\end{tabular}

50 individuals/pond) were weekly weighed and measured and the daily amount of feeds was corrected according to the attained weight and observed feeding behaviour and consumption as well as water temperature. The dissolved oxygen level was checked twice a week and maintained above $80 \%$ with paddlewheel aerators. During the season, the water temperature in ponds fluctuated between 16 and $30^{\circ} \mathrm{C}$. Accordingly, the abovementioned daily feed rations varied between 1.5 and $3.2 \%$ of metabolic body weight $\left(\mathrm{MBW} \% \mathrm{~kg}^{-0.8}\right)$. During the rearing season, the zooplankton production of the ponds was evaluated. The trial lasted 136 days and, after harvesting, the fish were kept in the overwintering small ponds $\left(300 \mathrm{~m}^{2}\right)$. Overwintering starvation of the fish ended after 5 months, and fish were stocked in ponds similar to initial ones with stocking densities of around 5000/ha. The feeding trial in the second year lasted overall 223 days and the daily feed rations varied from 0.6 to $3.5 \% \mathrm{MBW} \% \mathrm{~kg}^{-0.8}$. The ponds were manured with $3 \times 150 \mathrm{~kg} /$ pond cow manure.
Again, in the winter period, fish were kept in wintering ponds without feeding. In the third year, the feeding was continued in triplicate ponds with densities of 1000 fish/ha. In September, when fish reached the market size of approx. $2 \mathrm{~kg}$, they were harvested.

Fish were humanly slaughtered with a sharp blow to the head. Fish were kept on wet ice in a cold room $\left(0^{\circ} \mathrm{C}\right)$; ice was added daily in order to replace the melting one and excess water was drained. Fish were assessed for their sensory freshness, sampling for $K$-value analysis (chemical freshness) took place, and samples were shipped to HCMR for analysis.

2.2. Sensory Freshness. For all fish species, the Quality Index Method (QIM) was used to assess their sensory freshness. QIM is a standardized method developed in the late ' $80 \mathrm{~s}$ with the aim of increasing the objectivity of sensory methods, being practical and integrative bridging between research and fish chain stakeholders [35]. QIM uses demerit scores 
TABLE 4: QIM scheme developed for rainbow trout (Oncorhynchus mykiss).

\begin{tabular}{|c|c|c|}
\hline Feature & Description & Score \\
\hline \multicolumn{3}{|l|}{ Skin } \\
\hline \multirow{4}{*}{ Colour/appearance } & Pearl-shiny all over skin & 0 \\
\hline & Less shiny, slight pink discoloration on the side & 1 \\
\hline & Less shiny, pink-red discoloration on the side \& gill cover & 2 \\
\hline & Less shiny, red-brown discoloration on the side \& gill cover & 3 \\
\hline \multirow{3}{*}{ Mucus } & Clear not clotted & 0 \\
\hline & Milky \& clotted or & 1 \\
\hline & Yellow \& clotted & 2 \\
\hline \multirow{4}{*}{ Odour } & Fresh, seaweed, cucumber & 0 \\
\hline & Neutral to metal, dry grass, corn & 1 \\
\hline & Sour & 2 \\
\hline & Rotten & 3 \\
\hline \multicolumn{3}{|l|}{ Eyes } \\
\hline \multirow{3}{*}{ Pupils } & Clear \& black, metal shiny & 0 \\
\hline & Lightly opaque & 1 \\
\hline & Mat, grey & 2 \\
\hline \multirow{3}{*}{ Form } & Flat & 0 \\
\hline & Little sunken & 1 \\
\hline & Sunken & 2 \\
\hline \multicolumn{3}{|l|}{ Abdomen } \\
\hline \multirow{2}{*}{ Colour } & White & 0 \\
\hline & Yellowish & 1 \\
\hline \multirow{4}{*}{ Odour } & Neutral & 0 \\
\hline & Corn & 1 \\
\hline & Sour & 2 \\
\hline & Rotten & 3 \\
\hline \multicolumn{3}{|l|}{ Gills } \\
\hline \multirow{3}{*}{ Colour/appearance } & Red/dark brown & 0 \\
\hline & Light red/pink/brown & 1 \\
\hline & Grey-brown/grey/green & 2 \\
\hline \multirow{3}{*}{ Mucus } & Transparent & 0 \\
\hline & White or dry & 1 \\
\hline & Yellow clotted & 2 \\
\hline \multirow{4}{*}{ Odour } & Fresh seaweed & 0 \\
\hline & Neutral- metal & 1 \\
\hline & Sour & 2 \\
\hline & Rotten & 3 \\
\hline \multicolumn{3}{|l|}{ Texture } \\
\hline \multirow{2}{*}{ Elasticity } & Finger mark disappears immediately & 0 \\
\hline & Finger leaves mark over $3 \mathrm{~s}$ & 1 \\
\hline Total demerit score & & 24 \\
\hline
\end{tabular}

to separately rate freshness characteristics of whole fresh fish in aspects of external appearance, odour, and texture. Within these, the skin, eyes, gills, and abdomen are evaluated. Each fish species has an individual QIM scheme based on the inherent individualities of the species.

The Quality Index Method (QIM) freshness evaluation scheme, previously developed for salmon (Sveindottir et al., 2000), has been changed accordingly to match the rainbow trout freshness and spoilage features, and based on that, evaluation took place. The QIM scheme that was developed for rainbow trout consisted of 24 demerit points and is presented in Table 4. Sensory evaluation of freshness of seven fish per treatment took place at certain time intervals by 4 trained panelists. Freshness evaluation for rainbow trout took place on days $0,3,6,9,14$, and 19 of ice storage.

The Quality Index Method developed by Huidobro et al. [27] for gilthead sea bream was used with a slight modification after a preliminary trial. In particular, for aspects of 
TABLE 5: QIM scheme used for gilthead sea bream (Sparus aurata).

\begin{tabular}{|c|c|c|}
\hline Feature & Description & Score \\
\hline \multicolumn{3}{|l|}{ Appearance } \\
\hline \multirow{3}{*}{ Skin } & Very bright & 0 \\
\hline & Bright & 1 \\
\hline & Dull & 2 \\
\hline \multirow{2}{*}{ Slime } & Clear/transparent & 0 \\
\hline & Absence of slime & 1 \\
\hline \multicolumn{3}{|l|}{ Flesh } \\
\hline \multirow{2}{*}{ Elasticity } & Elastic & 0 \\
\hline & Marked by pressure & 1 \\
\hline \multirow{4}{*}{ Odour } & Fresh & 0 \\
\hline & Neutral & 1 \\
\hline & Fishy & 2 \\
\hline & Off odors & 3 \\
\hline \multicolumn{3}{|l|}{ Eyes } \\
\hline \multirow{3}{*}{ clarity } & Clear-translucent & 0 \\
\hline & Slightly opaque & 1 \\
\hline & Opaque/bloody & 2 \\
\hline \multirow{2}{*}{ Shape } & Convex & 0 \\
\hline & Flat & 1 \\
\hline \multicolumn{3}{|l|}{ Gills } \\
\hline \multirow{2}{*}{ colour } & Bright/dark red & 0 \\
\hline & Brownish red/discolored & 1 \\
\hline \multirow{4}{*}{ smell } & Fresh/seaweed & 0 \\
\hline & Neutral & 1 \\
\hline & Fishy & 2 \\
\hline & Off odors & 3 \\
\hline Total demerit score & & 15 \\
\hline
\end{tabular}

slime, it was decided that a score of 1 better represented the absence of slime (i.e., dryness) instead of cloudy slime, while in aspects of eye shape, only convex and flat were kept, since no concave eyes were observed for spoilt fish state (Table 5). A total of 5 trained panelists examined fish freshness at various postmortem time intervals, specifically on days $2,7,11,15$, and 17 of ice storage. In total, six fish per treatment were examined at each time interval.

For common carp, the QIM scheme developed by Ochrem et al. [36] with 31 demerit points was used unchanged. The carp were evaluated for their sensory freshness by 6 trained panelists. Nine individuals per dietary treatment were assessed for their sensory freshness at various postmortem time intervals (days $0,2,4,6,8,10,12,14,16,18$, and 19).

The fact that the different species were not assessed at the same time intervals had to do with different time limitations, that is, with when fish samplings and shipments were scheduled and the time intervals at which all panelists were available to simultaneously perform freshness assessment.

2.3. Chemical Freshness. For the 3 species, five fillet samples per dietary treatment were used for ATP breakdown products analysis. These analyses were carried out at each postmortem time interval.

Extraction of ATP breakdown products took place from $5 \mathrm{~g}$ of dorsal muscle. Tissue was finely chopped and homogenized with $25 \mathrm{ml}$ of perchloric acid $(0.6 \mathrm{M})$ for 2 minutes under ice. The homogenate was then centrifuged at $2^{\circ} \mathrm{C}$ at $3,000 \mathrm{rpm}$ for $10 \mathrm{~min}$, and $10 \mathrm{ml}$ of the supernatant was accurately received and subsequently buffered at $\mathrm{pH}$ 6.7-6.9 with $2 \mathrm{~N} \mathrm{KOH}$. Samples were placed in ice for $30 \mathrm{~min}$ to allow precipitation of $\mathrm{KClO}_{4}$ and proteins, volumetrically measured, and then kept at $-20^{\circ} \mathrm{C}$ until analysis. The instruments for analysis consisted of a Waters 717 Plus Autosampler set at $10^{\circ} \mathrm{C}$ injection temperature, a Macherey-Nagel (Düren, Germany) column 250/4 Nucleosil 100-5 C18, a Waters 2487 UV detector set at a wavelength of $254 \mathrm{~nm}$, and Waters Empower ${ }^{\mathrm{TM}}$ Chromatography Software (Waters, Milford, MA, 01757). As a mobile phase, an aqueous solution of $\mathrm{KH}_{2} \mathrm{PO}_{4}(0.04 \mathrm{M})$ and $\mathrm{K}_{2} \mathrm{HPO}_{4}(0.06 \mathrm{M})$ was used, and the flow rate was $1.5 \mathrm{ml} / \mathrm{min}$. The injected volume was $5 \mu \mathrm{l}$. Standard curves were constructed for adenosine $5^{\prime}$-triphosphate (ATP), adenosine $5^{\prime}$ diphosphate (ADP), adenosine $5^{\prime}$-monophosphate (AMP), inosine $5^{\prime}$-monophosphate (IMP), inosine (Ino), and hypoxanthine (Hx) (Sigma-Aldrich, USA). The ATP breakdown products of the samples were quantified by comparison of 


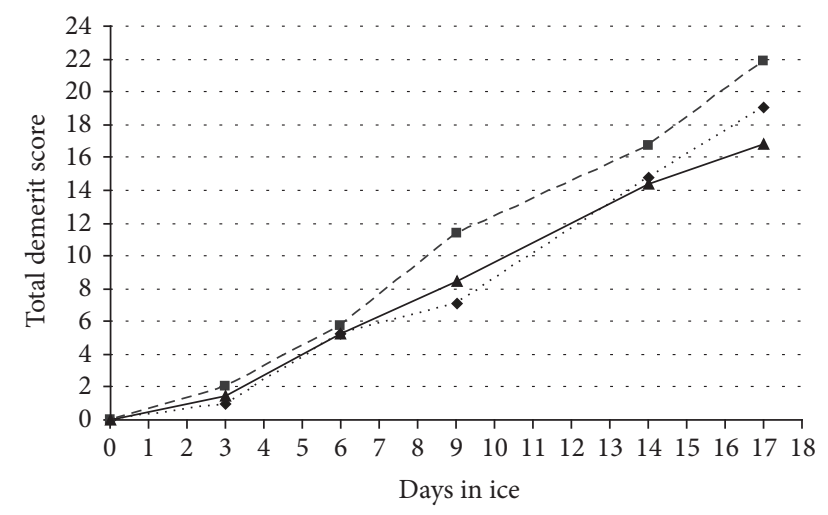

$\ldots \leftrightarrow \mathrm{C}$
$-\square \mathrm{V}$
$\longleftarrow \mathrm{M}$

FIGURE 1: QIM freshness sensory scores for the three rainbow trout dietary groups (C: commercial diet; M: marine diet; V: plant-based diet) stored in ice.

their chromatogram areas with the standard curves. The $K$ values were calculated according to Saito et al. (1959) as follows:

$$
\begin{aligned}
K(\%)= & {\left[\frac{(\text { Ino }+\mathrm{Hx})}{(\mathrm{ATP}+\mathrm{ADP}+\mathrm{AMP}+\mathrm{IMP}+\mathrm{Ino}+\mathrm{Hx})}\right] } \\
& * 100
\end{aligned}
$$

2.4. Statistical Analysis. For detection of differences between dietary groups within each sampling interval, one-way analysis of variance (ANOVA) was applied; after homogeneity check, Tukey-HSD test, with 95\% confidence intervals, was applied for comparing the means. Linear regression was performed for all ATP breakdown products and in all dietary groups for the three species studied in order to evaluate their change rates.

\section{Results and Discussion}

The QIM scores that the three rainbow trout dietary groups received are presented in Figure 1. A period of 6 days of ice storage was that of fish retaining their extra freshness characteristics, while 14 days of ice storage has been recorded by the panelists as the sensory acceptability limit for whole raw rainbow trout. This is similar to what has been proposed in other studies, using the EU or salmon QIM sensory freshness schemes to evaluate ice-stored rainbow trout $[37,38]$. The three dietary groups differed in their sensory spoilage, with plant-fed fish (V) exhibiting worse sensory freshness than the other two groups $(p<0.05)$ from the 9th day forward.

The $K$-values for $\mathrm{C}, \mathrm{V}$, and $\mathrm{M}$ rainbow trout groups increased from the initial $16.4,13.62$, and $15.46 \%$ on day 0 to reach $84.4,83.6$, and $86.2 \%$, respectively, on the 17 th day of ice storage (Figure 2). No statistically significant differences have been observed between the different diets, for any of the ice storage time intervals. The $K$-values found herein at the sensory acceptability limit and at the end of the storage were

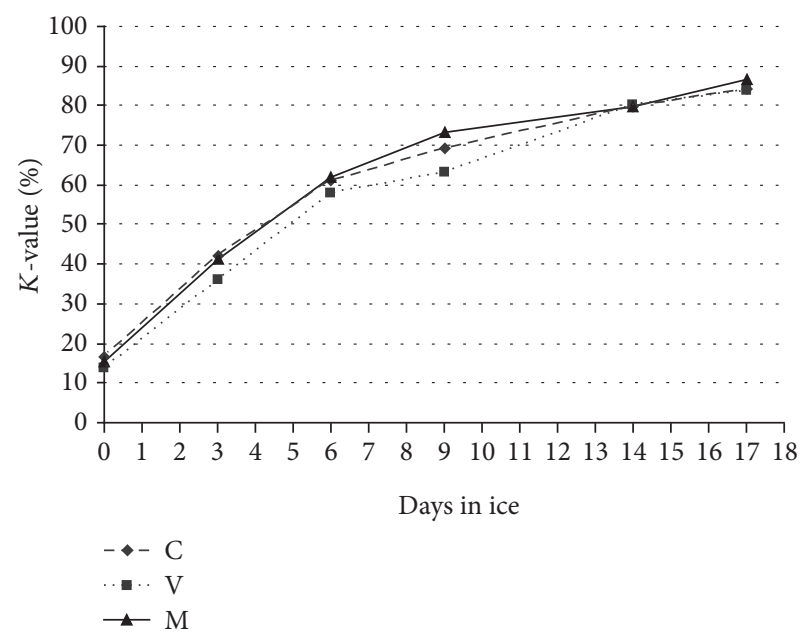

FIGURE 2: $K$-value (\%) of the three rainbow trout groups (C: commercial diet; M: marine diet; V: plant-based diet) stored in ice.

very similar to those reported on the same species after 14-15 and $17-18$ days of storage in ice $(72.0-78.1 \%$ and $84.0-92.5 \%$, resp.) $[30,39]$.

Since ATP breakdown to IMP is a rapid procedure and IMP is the main ATP metabolite in freshly killed fish [40], the ATP, ADP, and AMP remained at low concentrations throughout the storage (results not shown), and therefore only IMP, Ino, and Hx changes are presented for all the three species studied.

The three rainbow trout dietary groups exhibited, further to the sensory freshness, some differences in the IMP, Ino, and $\mathrm{Hx}$ change patterns (Table 6). Thus, the $\mathrm{V}$ group showed higher $\mathrm{Hx}$ concentration $(p<0.05)$ at the end of the storage period. This is a chemical finding that indicates worse freshness of $\mathrm{V}$ group at the end of the storage period, in accordance with the sensory evaluation. However, no similar pattern to QIM changes was observed in individual ATP breakdown products.

Linear regression gives a good fit for all individual breakdown products' changes, and this corresponds to high $R^{2}$ values in all cases. Although linear regression is a compromise, since the IMP decomposition path rather follows an enzyme kinetics model further complicated with breakdown components' leaching [41], the slopes in linear regression give a good indication of the IMP reduction rates. The linear regressions showed no differences in IMP reduction rates, as indicated by the slopes (Table 6).

Our results in regard to ATP breakdown products in rainbow trout only partly agree with those of Howgate [42]. Thus, IMP reduction showed a similar pattern to that mentioned in the previous study for seawater-reared fish, but not to that mentioned for freshwater fish that exhibited a rapid reduction to zero levels within 14 days of ice storage. Also, the levels of Ino and $\mathrm{Hx}$ for all studied groups herein were lower than those mentioned by Howgate (2005) for similar storage periods. However, differences in the components' absolute concentrations, between different studies, can be possibly attributed to the variable degree of leaching associated with 
TABLE 6: Individual ATP breakdown product concentrations in $\mu \mathrm{mol} \mathrm{g}^{-1}$ fish fillet in rainbow trout fed with the three experimental diets (C, $\mathrm{M}$, and V). Data are mean \pm SD $(n=5)$. Means not sharing a common superscript letter are significantly different $(p<0.05)$. IMP: inosine monophosphate; Ino: inosine; Hx: hypoxanthine.

\begin{tabular}{|c|c|c|c|}
\hline Days in ice & $\mathrm{C}$ & $\mathrm{V}$ & $\mathrm{M}$ \\
\hline \multicolumn{4}{|l|}{$I M P$} \\
\hline 0 & $5.40 \pm 0.64$ & $5.14 \pm 1.15$ & $5.30 \pm 0.44$ \\
\hline 3 & $3.79 \pm 0.66$ & $4.28 \pm 0.85$ & $3.07 \pm 0.91$ \\
\hline 6 & $2.49 \pm 1.09$ & $2.11 \pm 0.30$ & $1.63 \pm 0.80$ \\
\hline 9 & $1.19 \pm 0.92$ & $1.61 \pm 0.69$ & $0.98 \pm 0.45$ \\
\hline 14 & $0.69 \pm 0.54$ & $0.51 \pm 0.49$ & $0.57 \pm 0.30$ \\
\hline 17 & $0.27 \pm 0.18$ & $0.33 \pm 0.36$ & $0.27 \pm 0.13$ \\
\hline Linear regression & $\begin{array}{c}-0.292 x+4.694 \\
R^{2}=0.91\end{array}$ & $\begin{array}{c}-0.292 x+4.709 \\
R^{2}=0.91\end{array}$ & $\begin{array}{c}-0.2663 x+4.145 \\
R^{2}=0.82\end{array}$ \\
\hline \multicolumn{4}{|l|}{ Ino } \\
\hline 0 & $1.07 \pm 0.14^{\mathrm{b}}$ & $0.81 \pm 0.16^{\mathrm{a}}$ & $0.96 \pm 0.13^{\mathrm{ab}}$ \\
\hline 3 & $2.85 \pm 0.53$ & $2.43 \pm 0.59$ & $2.15 \pm 0.42$ \\
\hline 6 & $3.99 \pm 0.92$ & $3.19 \pm 0.99$ & $2.67 \pm 0.38$ \\
\hline 9 & $2.67 \pm 0.58$ & $2.87 \pm 0.32$ & $3.01 \pm 0.59$ \\
\hline 14 & $3.41 \pm 0.95$ & $2.37 \pm 0.86$ & $2.83 \pm 0.79$ \\
\hline 17 & $2.18 \pm 0.44^{\mathrm{a}}$ & $2.05 \pm 0.79^{\mathrm{ab}}$ & $2.96 \pm 0.56^{\mathrm{b}}$ \\
\hline Linear regression & $\begin{array}{c}9.758 x+18.06 \\
R^{2}=0.64 \\
\end{array}$ & $\begin{array}{c}12.45 x+9.403 \\
R^{2}=0.80\end{array}$ & $\begin{array}{c}13.48 x+9.491 \\
R^{2}=0.85\end{array}$ \\
\hline \multicolumn{4}{|l|}{$H x$} \\
\hline 0 & $0.08 \pm 0.02^{b}$ & $0.04 \pm 0.01^{\mathrm{a}}$ & $0.08 \pm 0.02^{b}$ \\
\hline 3 & $0.23 \pm 0.04$ & $0.22 \pm 0.03$ & $0.17 \pm 0.03$ \\
\hline 6 & $0.41 \pm 0.07^{\mathrm{b}}$ & $0.32 \pm 0.14^{\mathrm{ab}}$ & $0.23 \pm 0.04^{\mathrm{a}}$ \\
\hline 9 & $0.30 \pm 0.07$ & $0.33 \pm 0.06$ & $0.33 \pm 0.05$ \\
\hline 14 & $0.49 \pm 0.10$ & $0.44 \pm 0.12$ & $0.41 \pm 0.05$ \\
\hline 17 & $0.48 \pm 0.18^{\mathrm{a}}$ & $0.68 \pm 0.11^{\mathrm{b}}$ & $0.51 \pm 0.03^{\mathrm{a}}$ \\
\hline Linear regression & $\begin{array}{c}0.033 x+0.105 \\
R^{2}=0.85\end{array}$ & $\begin{array}{c}0.032 x+0.079 \\
R^{2}=0.92\end{array}$ & $\begin{array}{c}0.025 x+0.087 \\
R^{2}=0.99\end{array}$ \\
\hline
\end{tabular}

the solutes' diffusion rates through fish muscle and skin and also with the rate of melting and the quantity of ice present during ice storage preservation [41]. The same mechanism of leaching can also explain the total reduction of the sum of ATP metabolites absolute concentrations (55,3\%, 48,9\%, and $41 \%$ reduction for $\mathrm{C}, \mathrm{V}$, and $\mathrm{M}$, resp.) occurring herein with storage time (Table 6).

Current results also indicate that the rainbow trout accumulates Ino, while there is also an accumulation of $\mathrm{Hx}$ but at a lower rate (Table 6), thus classifying this species somewhere between Ino-accumulating species like mackerel and Hx-accumulating species like flatfish [43].

The gilthead sea bream QIM scores did not differentiate between the different dietary treatments (Figure 3). The sensory shelf life of 15 days of ice storage, corresponding to a QIM score of about 10 demerit points, is similar to that previously reported for this species [17, 28, 44, 45]. The $K$ values also showed no differentiation among dietary groups. They increased from initially 6.7, 6.7, 6.1, and $5.9 \%$ on day 2 to $36.5,35.8,38.5$, and $39.8 \%$ on the 17 th day of ice storage for diets D1, D2, D3, and D4, respectively (Figure 4).

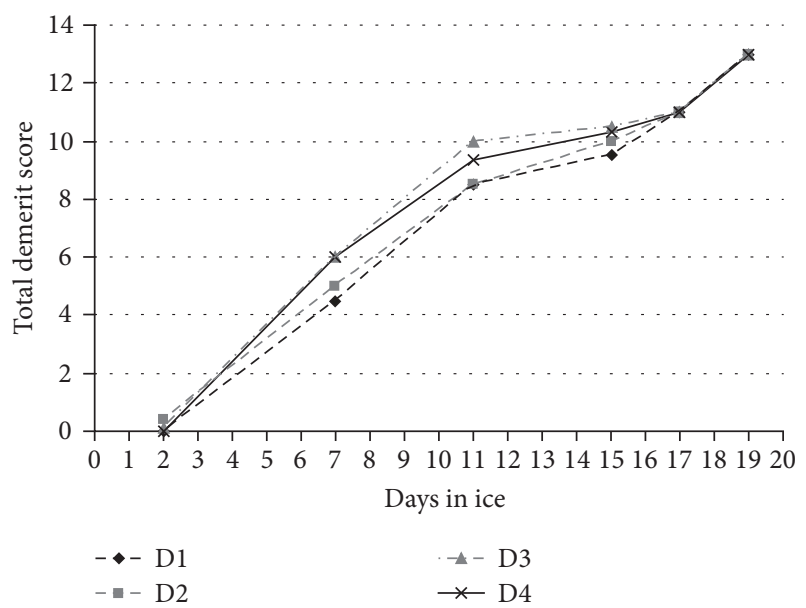

FIGURE 3: QIM freshness sensory scores for the four gilthead sea bream dietary groups (D1-D4) stored in ice.

Although the individual breakdown products are not different at initial postmortem stages (days 2, 4, and 7), there 
TABLE 7: Individual ATP breakdown product concentrations in $\mu \mathrm{mol} \mathrm{g}^{-1}$ fish fillet in gilthead sea bream fed with the four experimental diets (D1-D4). Data are mean \pm SD $(n=5)$. Means not sharing a common superscript letter are significantly different $(p<0.05)$. IMP: inosine monophosphate; Ino: inosine; Hx: hypoxanthine.

\begin{tabular}{|c|c|c|c|c|}
\hline Days in ice & D1 & $\mathrm{D} 2$ & D3 & $\mathrm{D} 4$ \\
\hline \multicolumn{5}{|l|}{ IMP } \\
\hline 2 & $6.45 \pm 0.32$ & $6.06 \pm 0.65$ & $6.46 \pm 0.74$ & $7.33 \pm 0.13$ \\
\hline 4 & $6.34 \pm 0.24$ & $5.94 \pm 0.28$ & $6.36 \pm 0.31$ & $6.42 \pm 0.09$ \\
\hline 7 & $5.07 \pm 1.27$ & $6.35 \pm 0.23$ & $5.57 \pm 0.37$ & $5.19 \pm 0.13$ \\
\hline 10 & $5.62 \pm 0.10$ & $5.67 \pm 0.12$ & $5.39 \pm 0.07$ & $5.46 \pm 0.28$ \\
\hline 14 & $4.83 \pm 0.11^{\mathrm{b}}$ & $5.11 \pm 0.17^{\mathrm{b}}$ & $3.42 \pm 0.31^{\mathrm{a}}$ & $3.37 \pm 0.43^{\mathrm{a}}$ \\
\hline 17 & $4.34 \pm 0.22^{\mathrm{b}}$ & $4.45 \pm 0.17^{\mathrm{b}}$ & $2.78 \pm 0.32^{\mathrm{a}}$ & $3.36 \pm 0.28^{\mathrm{a}}$ \\
\hline Linear regression & $\begin{array}{c}-0.134 x+6.648 \\
R^{2}=0.85\end{array}$ & $\begin{array}{c}-0.118+6.713 \\
R^{2}=0.85\end{array}$ & $\begin{array}{c}-0.258 x+7.322 \\
R^{2}=0.94\end{array}$ & $\begin{array}{c}-0.265 x+7.575 \\
R^{2}=0.92\end{array}$ \\
\hline \multicolumn{5}{|l|}{ Ino } \\
\hline 2 & $0.37 \pm 0.04$ & $0.36 \pm 0.04$ & $0.34 \pm 0.07$ & $0.37 \pm 0.06$ \\
\hline 4 & $0.80 \pm 0.11$ & $0.69 \pm 0.04$ & $0.71 \pm 0.13$ & $0.71 \pm 0.09$ \\
\hline 7 & $1.13 \pm 0.29$ & $1.30 \pm 0.11$ & $1.18 \pm 0.03$ & $1.17 \pm 0.10$ \\
\hline 10 & $1.57 \pm 0.07$ & $1.61 \pm 0.06$ & $1.18 \pm 0.14$ & $1.71 \pm 0.09$ \\
\hline 14 & $1.87 \pm 0.10^{\mathrm{bc}}$ & $1.98 \pm 0.09^{c}$ & $1.48 \pm 0.12^{\mathrm{a}}$ & $1.63 \pm 0.11^{\mathrm{ab}}$ \\
\hline 17 & $2.17 \pm 0.23$ & $2.21 \pm 0.16$ & $1.64 \pm 0.24$ & $2.07 \pm 0.26$ \\
\hline Linear regression & $\begin{array}{c}0.115 x+0.277 \\
R^{2}=0.98\end{array}$ & $\begin{array}{c}0.104 x+0489 \\
R^{2}=0.96\end{array}$ & $\begin{array}{c}0.082 x+0.407 \\
R^{2}=0.84\end{array}$ & $\begin{array}{c}0.106 x+0.314 \\
R^{2}=0.91\end{array}$ \\
\hline \multicolumn{5}{|l|}{$\mathrm{Hx}$} \\
\hline 2 & $0.12 \pm 0.07$ & $0.10 \pm 0.02$ & $0.11 \pm 0.00$ & $0.12 \pm 0.01$ \\
\hline 4 & $0.21 \pm 0.05$ & $0.15 \pm 0.02$ & $0.18 \pm 0.85$ & $0.18 \pm 0.02$ \\
\hline 7 & $0.28 \pm 0.02$ & $0.26 \pm 0.05$ & $0.26 \pm 0.01$ & $0.23 \pm 0.04$ \\
\hline 10 & $0.36 \pm 0.11$ & $0.30 \pm 0.03$ & $0.18 \pm 0.14$ & $0.25 \pm 0.06$ \\
\hline 14 & $0.41 \pm 0.10$ & $0.34 \pm 0.02$ & $0.26 \pm 0.03$ & $0.30 \pm 0.06$ \\
\hline 17 & $0.55 \pm 0.05^{\mathrm{c}}$ & $0.47 \pm 0.03^{\mathrm{bc}}$ & $0.26 \pm 0.01^{\mathrm{a}}$ & $0.33 \pm 0.09^{\mathrm{ab}}$ \\
\hline Linear regression & $\begin{array}{c}0.026 x+0.085 \\
R^{2}=0.97\end{array}$ & $\begin{array}{c}0.017 x+0.127 \\
R^{2}=0.89\end{array}$ & $\begin{array}{c}-0.006 x+0.348 \\
R^{2}=0.30\end{array}$ & $\begin{array}{c}0.013 x+0.117 \\
R^{2}=0.96\end{array}$ \\
\hline
\end{tabular}

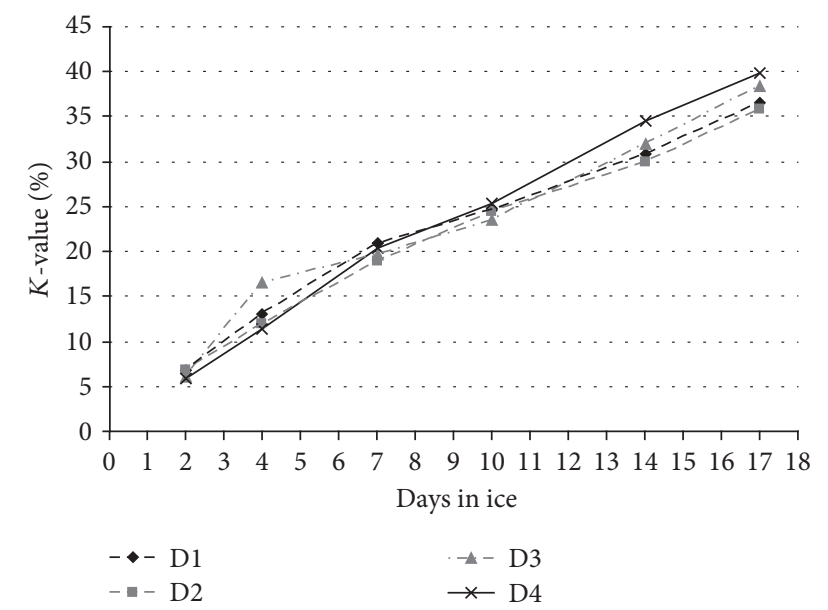

FIGURE 4: $K$-value (\%) of the four gilthead sea bream dietary groups (D1-D4) stored in ice.

is a differentiation in the later spoilage days with D1 and D2 exhibiting higher IMP preservation than the D3 and
D4 dietary groups that are those with the highest FM/FO substitution level (Table 7). Besides, the D3 and D4 diets show a much quicker IMP decrease rate, as indicated by the slopes in linear regressions (Table 7). The IMP is associated with sweetness and pleasant flavour displayed by fresh fish [41] and thus slightly better preservation can be assumed for the two dietary groups that received higher dietary fish raw materials (D1: higher FM/FO, D2: higher FO). On the other hand, the same dietary groups exhibited higher Ino concentrations on day 14 of ice storage and higher Hx concentration on day 17 (Table 7).

Gilthead sea bream follows a quite similar spoilage pattern to that of rainbow trout, with high accumulation of Ino and slow accumulation of $\mathrm{Hx}$ (Table 7). This spoilage pattern is confirmed by previous studies on the same species $[17,40$, 46].

No differences were observed in the sensory spoilage of the three carp dietary groups. The carp exhibited a sensory shelf life of 12 days, corresponding to a QIM score exceeding the 18 demerit points (Figure 5). This is shorter than the 16-18 days mentioned for the same species in previous studies 
TABLE 8: IMP, Ino, and Hx concentrations in $\mu \mathrm{mol} \mathrm{g}^{-1}$ muscle for common carp fed with the three experimental diets (C, P, and F) and stored on ice for 0-12 days postmortem. IMP: inosine monophosphate; Ino: inosine; Hx: hypoxanthine.

\begin{tabular}{|c|c|c|c|}
\hline Days in ice & $\mathrm{C}$ & $\mathrm{P}$ & $\mathrm{F}$ \\
\hline \multicolumn{4}{|l|}{ IMP } \\
\hline 0 & $3.69 \pm 1.23$ & $2.84 \pm 0.17$ & $4.04 \pm 0.30$ \\
\hline 2 & $2.07 \pm 0.76$ & $1.88 \pm 0.77$ & $2.33 \pm 1.13$ \\
\hline 4 & $1.64 \pm 1.16$ & $1.02 \pm 0.54$ & $1.52 \pm 1.69$ \\
\hline 6 & $0.82 \pm 0.63$ & $0.52 \pm 0.74$ & $0.33 \pm 0.35$ \\
\hline 8 & $0.18 \pm 0.11$ & $0.14 \pm 0.12$ & $0.27 \pm 0.28$ \\
\hline 10 & $0.33 \pm 0.32$ & $0.03 \pm 0.02$ & $0.04 \pm 0.01$ \\
\hline 12 & $0.28 \pm 0.19$ & $0.03 \pm 0.01$ & $0.07 \pm 0.02$ \\
\hline Linear regression & $\begin{array}{c}-0.271 x+2.916 \\
R^{2}=0.83\end{array}$ & $\begin{array}{c}-0.316 x+3.126 \\
R^{2}=0.82\end{array}$ & $\begin{array}{c}-0.232 x+2.317 \\
R^{2}=0.87\end{array}$ \\
\hline \multicolumn{4}{|l|}{ Ino } \\
\hline 0 & $0.37 \pm 0.10$ & $0.34 \pm 0.07$ & $0.40 \pm 0.04$ \\
\hline 2 & $0.98 \pm 0.24$ & $0.73 \pm 0.10$ & $1.00 \pm 0.21$ \\
\hline 4 & $1.25 \pm 0.39$ & $1.07 \pm 0.15$ & $1.27 \pm 0.46$ \\
\hline 6 & $0.93 \pm 0.14$ & $0.82 \pm 0.28$ & $0.93 \pm 0.35$ \\
\hline 8 & $0.96 \pm 0.17$ & $0.63 \pm 0.06$ & $1.21 \pm 0.43$ \\
\hline 10 & $0.83 \pm 0.24$ & $0.37 \pm 0.18$ & $0.88 \pm 0.55$ \\
\hline 12 & $1.48 \pm 0.63$ & $0.53 \pm 0.34$ & $1.20 \pm 0.52$ \\
\hline Linear regression & $\begin{array}{c}0.049 x+0.675 \\
R^{2}=0.38\end{array}$ & $\begin{array}{c}0.037 x+0.762 \\
R^{2}=0.29\end{array}$ & $\begin{array}{c}-0.010 x+0.702 \\
R^{2}=0.31\end{array}$ \\
\hline \multicolumn{4}{|l|}{$\mathrm{Hx}$} \\
\hline 0 & $0.00 \pm 0.00$ & $0.00 \pm 0.00$ & $0.00 \pm 0.00$ \\
\hline 2 & $0.03 \pm 0.02$ & $0.04 \pm 0.01$ & $0.06 \pm 0.04$ \\
\hline 4 & $0.06 \pm 0.03$ & $0.06 \pm 0.03$ & $0.08 \pm 0.05$ \\
\hline 6 & $0.08 \pm 0.04$ & $0.07 \pm 0.03$ & $0.08 \pm 0.00$ \\
\hline 8 & $0.11 \pm 0.07$ & $0.07 \pm 0.02$ & $0.09 \pm 0.04$ \\
\hline 10 & $0.08 \pm 0.03$ & $0.05 \pm 0.01$ & $0.16 \pm 0.12$ \\
\hline 12 & $0.18 \pm 0.10$ & $0.08 \pm 0.04$ & $0.16 \pm 0.04$ \\
\hline Linear regression & $\begin{array}{c}0.012 x+0.003 \\
R^{2}=0.83\end{array}$ & $\begin{array}{c}0.082 x+0.407 \\
R^{2}=0.84\end{array}$ & $\begin{array}{c}0.004 x+0.027 \\
R^{2}=0.53 \\
\end{array}$ \\
\hline
\end{tabular}

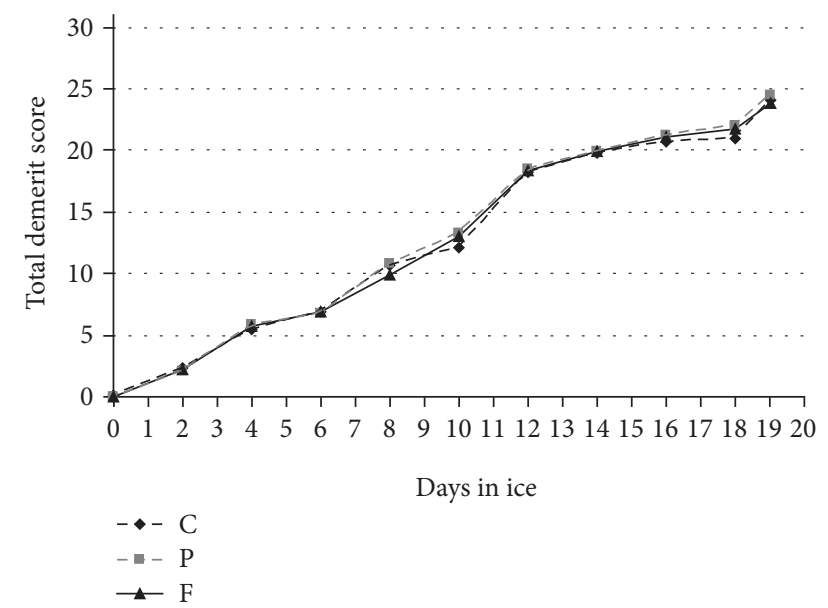

FIGURE 5: QIM freshness sensory scores for the three common carp groups (C: control diet; F: fish meal/fish oil diet; P: plant-based diet) stored in ice.
$[47,48]$. However, in the latter literature, although 18 days of shelf life was suggested, it was mentioned that degradationassociated flavour was detectable from the 13th day of ice storage [48]. On the other hand, our present results agree with the findings of Icekson et al. [49] who found a shelf life of 11 days in whole ice-stored carp. To some extent, the differences in the total sensory shelf life can be attributed to differentiations in preslaughter stress and conditions, killing procedure, and postmortem treatment and cold chain [7].

$K$-values in carp increased from the initial 9.2\%, $10.5 \%$, and $9.3 \%$ for the $\mathrm{C}, \mathrm{P}$, and $\mathrm{F}$ diets to the final values of $70.0 \%$, $65.6 \%$, and $72.4 \%$, respectively, on the 12 th day of ice storage, while no statistical differences were observed (Figure 6).

The carp is clearly an Ino-accumulating species, with $\mathrm{Hx}$ remaining very low throughout storage (Table 8). No significant differences have been observed among diets in the individual ATP breakdown products throughout ice storage. The almost negligible $\mathrm{Hx}$ accumulation clearly differentiates the carp from the other two species. Besides, another 


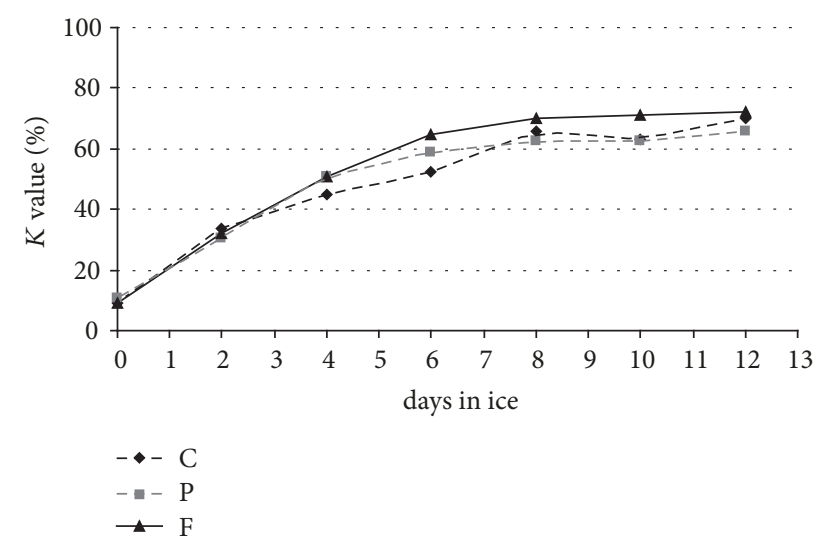

Figure 6: $K$-value (\%) for the three common carp groups (C: control diet; F: fish meal/fish oil diet; P: plant-based diet) stored in ice.

interesting observation is that linear regression does not give a good fit for Ino, as indicated by the low $R^{2}$ values. This implies that while IMP transformation to Ino is almost linear, as the high $R^{2}$ for IMP indicates, Ino is further decomposed to $\mathrm{Hx}$ or leached in a nonlinear way.

When comparing among the three species, rainbow trout seems to be more affected than the other two species. This could imply both species differentiation and impact of the degree of fish meal and fish oil substitution on the diets. Indeed, common carp is expected to have better adaptation to plant-based diets since it is an omnivorous species, unlike the other two species which are carnivorous species [50]. Besides, in rainbow trout, the $\mathrm{V}$ group that exhibited worse sensory spoilage (as indicated by its higher QIM scores) was the only one that received a total substituted diet, completely devoid of FM and FO and having zero levels of long chain polyunsaturated fatty acids, namely, 22:5n-3 (EPA) and 22:6n-3 (DHA).

In conclusion, it seems that long-term feeding (throughout the whole rearing cycle) with FM- and FO-substituted diets had slight effects on postmortem flesh quality and only on the later stages of spoilage in the case of rainbow trout. The potential reason for differentiation in spoilage pattern when dietary FM and FO are replaced can be possibly attributed to microbiota alterations in the intestine and mucus. It has been clearly indicated that fish gut microbiota is highly affected by a number of environmental parameters including diet [51]. Changes of intestinal microbiota have been indicated in rainbow trout when fed with plant-based diets and these include both the increase in numbers and the alteration of predominant microbe genera $[52,53]$. The late stages of ice storage are predominated by microbial activity deriving from the bacteria initially present in the fish intestine and mucus invading and metabolizing the tissues [43]. Whether a change in the microbial flora could also result in spoilage pattern changes remains to be experimentally confirmed.

\section{Conclusions}

A sensory acceptability limit of 14 days for rainbow trout, 15 days for gilthead sea bream, and 12 days for common carp was found. These corresponded to $K$-values of approximately $80 \%$ for rainbow trout, $35 \%$ for gilthead sea bream, and $65 \%$ for common carp.

In general, the present results for gilthead sea bream and common carp indicated no major effect of dietary history on postmortem shelf life; neither sensory-perceived (QIM) nor chemical ( $K$-values) freshness values showed significant differences due to dietary treatment. In rainbow trout, slightly worse sensory freshness, especially near the end of shelf life, was observed with the totally plant-based diet compared to the other 2 groups fed with FM- and FO-based diets.

These findings implied that, in terms of end product quality, a high level of dietary FM and FO substitution can be successfully used without major impacts on shelf life of fish products.

\section{Disclosure}

The views expressed in this work are the sole responsibility of the authors and do not necessarily reflect the views of the European Commission. An earlier version of this work was presented as a poster at the International Conference organized by the European Aquaculture Society (AE2016), 2016.

\section{Conflicts of Interest}

The authors declare that there are no conflicts of interest regarding the publication of this paper.

\section{Acknowledgments}

This study was funded by the European Union (ARRAINA, FP7-KBBE-2011-5-288925, Advanced Research Initiatives for Nutrition and Aquaculture).

\section{References}

[1] A. G. J. Tacon and M. Metian, "Global overview on the use of fish meal and fish oil in industrially compounded aquafeeds: Trends and future prospects," Aquaculture, vol. 285, no. 1-4, pp. 146-158, 2008.

[2] M. Jobling, "Fish nutrition research: past, present and future," Aquaculture International, vol. 24, no. 3, pp. 767-786, 2016.

[3] FAO., "The State of World Fisheries and Aquaculture 2016. Contributing to food security and nutrition for all".

[4] G. M. Turchini, B. E. Torstensen, and W.-K. Ng, "Fish oil replacement in finfish nutrition," Reviews in Aquaculture, vol. 1, no. 1, pp. 10-57, 2009.

[5] FAO, "Cultured Aquatic Species Information Programme. Oncorhynchus mykiss, Cultured Aquatic Species Information Programme 2005-2016," http://www.fao.org/fishery/culturedspecies/Oncorhynchus_mykiss/en.

[6] K. Grigorakis, "Fillet proximate composition, lipid quality, yields, and organoleptic quality of Mediterranean-farmed marine fish: A review with emphasis on new species," Critical Reviews in Food Science and Nutrition, vol. 57, no. 14, pp. 29562969, 2017.

[7] M. Sterniša, J. Mraz, and S. Smole Možina, "Microbiological aspects of common carp (Cyprinus carpio) and its 
processing-relevance for final product quality: a review," Aquaculture International, vol. 24, no. 6, pp. 1569-1590, 2016.

[8] G. Turchini, W. Ng, and D. Tocher, "The effects of fish oil replacement on nutritional and organoleptic qualities of farmed fish," in Fish Oil Replacement and Alternative Lipid Sources in Aquaculture Feeds, G. M. Turchini, N. G. Wing-Keong, and D. R. Tocher, Eds., pp. 487-522, CRC Press, Boca Raton, USA, 2010.

[9] G. M. Turchini, K. Hermon, V. M. Moretti et al., "Seven fish oil substitutes over a rainbow trout grow-out cycle: II) Effects on final eating quality and a tentative estimation of feed-related production costs," Aquaculture Nutrition, vol. 19, no. 1, pp. 95109, 2013.

[10] G. M. Turchini, T. Mentasti, F. Caprino, S. Panseri, V. M. Moretti, and F. Valfrè, "Effects of dietary lipid sources on flavour volatile compounds of brown trout (Salmo trutta L.) fillet," Journal of Applied Ichthyology, vol. 20, no. 1, pp. 71-75, 2004.

[11] G. M. Turchini, V. M. Moretti, K. Hermon et al., "Monola oil versus canola oil as a fish oil replacer in rainbow trout feeds: Effects on growth, fatty acid metabolism and final eating quality," Food Chemistry, vol. 141, no. 2, pp. 1335-1344, 2013.

[12] K. Grigorakis, E. Fountoulaki, I. Giogios, and M. N. Alexis, "Volatile compounds and organoleptic qualities of gilthead sea bream (Sparus aurata) fed commercial diets containing different lipid sources," Aquaculture, vol. 290, no. 1-2, pp. 116121, 2009.

[13] N. Alexi, E. Fountoulaki, and K. Grigorakis, "Quality of reared gilthead sea bream (Sparus aurata) during ice storage, as affected by dietary fish oil substitution; an instrumental and sensory designation approach," Aquaculture Research, vol. 48, no. 7, pp. 3817-3828, 2017.

[14] E. Matos, J. Dias, M. T. Dinis, and T. S. Silva, "Sustainability vs. Quality in gilthead seabream (Sparus aurata L.) farming: are trade-offs inevitable?" Reviews in Aquaculture, 2016.

[15] G. M. Turchini, V. M. Moretti, T. Mentasti, E. Orban, and F. Valfrè, "Effects of dietary lipid source on fillet chemical composition, flavour volatile compounds and sensory characteristics in the freshwater fish tench (Tinca tinca L.)," Food Chemistry, vol. 102, no. 4, pp. 1144-1155, 2007.

[16] H. H. Huss, "Quality and quality changes in fresh fish," FAO Fisheries Technical Paper - 348, Food and Agriculture Organization of the United Nation, Rome, 1995.

[17] K. Grigorakis, K. D. A. Taylor, and M. N. Alexis, "Seasonal patterns of spoilage of ice-stored cultured gilthead sea bream (Sparus aurata)," Food Chemistry, vol. 81, no. 2, pp. 263-268, 2003.

[18] A. Álvarez, B. García García, M. D. Garrido, and M. D. Hernández, "The influence of starvation time prior to slaughter on the quality of commercial-sized gilthead seabream (Sparus aurata) during ice storage," Aquaculture, vol. 284, no. 1-4, pp. 106-114, 2008.

[19] V. Šimat, T. Bogdanović, M. Krželj, A. Soldo, and J. MaršićLučić, "Differences in chemical, physical and sensory properties during shelf life assessment of wild and farmed gilthead sea bream (Sparus aurata, L.)," Journal of Applied Ichthyology, vol. 28, no. 1, pp. 95-101, 2012.

[20] P. E. Romotowska, M. G. Karlsdóttir, M. Gudjónsdóttir, H. G. Kristinsson, and S. Arason, "Influence of feeding state and frozen storage temperature on the lipid stability of Atlantic mackerel (Scomber scombrus)," International Journal of Food Science \& Technology, vol. 51, no. 7, pp. 1711-1720, 2016.

[21] K. Grigorakis, "Effects of nutrition and aquaculture practices on fish quality," in Handbook of Seafood Quality, Safety and Health
Applications, A. Cesarettin, Ed., pp. 82-95, Wiley-Blackwell, Oxford, UK, 2010.

[22] E. M. Cabral, T. J. R. Fernandes, S. D. Campos et al., "Replacement of fish meal by plant protein sources up to $75 \%$ induces good growth performance without affecting flesh quality in ongrowing Senegalese sole," Aquaculture, vol. 380-383, pp. 130138, 2013.

[23] S. Shen, Y. Jiang, X. Liu, Y. Luo, and L. Gao, "Quality assessment of rainbow trout (Oncorhynchus mykiss) fillets during super chilling and chilled storage," Journal of Food Science and Technology, vol. 52, no. 8, pp. 5204-5211, 2015.

[24] R. O. A. Ozório, J. Kopecka-Pilarczyk, M. J. Peixoto et al., "Dietary probiotic supplementation in juvenile rainbow trout (Oncorhynchus mykiss) reared under cage culture production: effects on growth, fish welfare, flesh quality and intestinal microbiota," Aquaculture Research, vol. 47, no. 9, pp. 2732-2747, 2016.

[25] N. Erkan, "Freshness and quality of aquacultured sea bass (Dicentrarchus labrax) and sea bream (Sparus aurata) stored in ice," Archiv für Lebensmittelhygiene, vol. 58, no. 3, pp. 98-106, 2007.

[26] A. Giuffrida, G. Ziino, L. Pennisi, A. Panebianco, and G. Donato, "Comparative study on shelf-life of reared Sparidae," Industrie Alimentari, vol. 44, no. 446, pp. 381-386, 2005.

[27] A. Huidobro, A. Pastor, and M. Tejada, "Quality index method developed for raw gilthead seabream (Sparus aurata)," Journal of Food Science, vol. 65, no. 7, pp. 1202-1205, 2000.

[28] B. Kilinc, S. Cakli, A. Cadun, T. Dincer, and S. Tolasa, "Comparison of effects of slurry ice and flake ice pretreatments on the quality of aquacultured sea bream (Sparus aurata) and sea bass (Dicentrarchus labrax) stored at $4^{\circ} \mathrm{C}$, Food Chemistry, vol. 104, no. 4, pp. 1611-1617, 2007.

[29] M. De Francesco, G. Parisi, F. Médale, P. Lupi, S. J. Kaushik, and B. M. Poli, "Effect of long-term feeding with a plant protein mixture based diet on growth and body/fillet quality traits of large rainbow trout (Oncorhynchus mykiss)," in Biotechnology for quality. Aquaculture Europe 04. European Aquaculture Society Meeting, vol. 236, pp. 413-429, 2004.

[30] Y. Özogul, J. I. Ahmad, M. Hole, F. Özogul, and S. Deguara, “The effects of partial replacement of fish meal by vegetable protein sources in the diet of rainbow trout (Onchorynchus mykiss) on post mortem spoilage of fillets," Food Chemistry, vol. 96, no. 4, pp. 549-561, 2006.

[31] D. R. Tocher, "Metabolism and functions of lipids and fatty acids in teleost fish," Reviews in Fisheries Science, vol. 11, no. 2, pp. 107184, 2003.

[32] M. Jobling, "National Research Council (NRC): Nutrient requirements of fish and shrimp," Aquaculture International, vol. 20, no. 3, pp. 601-602, 2012.

[33] L. Benedito-Palos, G. F. Ballester-Lozano, P. Simó et al., "Lasting effects of butyrate and low FM/FO diets on growth performance, blood haematology/biochemistry and molecular growth-related markers in gilthead sea bream (Sparus aurata)," Aquaculture, vol. 454, pp. 8-18, 2016.

[34] European Food Safety Authority, "Species-specific welfare aspects of the main systems of stunning and killing of farmed Seabass and Seabream," EFSA Journal, vol. 7, no. 4, pp. 1-52, 2009.

[35] G. Hyldig and D. M. B. Green-Petersen, "Quality index methodan objective tool for determination of sensory quality," Journal of Aquatic Food Product Technology, vol. 13, no. 4, pp. 71-80, 2004 . 
[36] A. S. Ochrem, P. Zapletal, D. Maj, Z. Gil, and J. ZychlińskaBuczek, "Changes in physical and dielectrical properties of carp meat (Cyprinus carpio) during cold storage," Journal of Food Process Engineering, vol. 37, no. 2, pp. 177-184, 2014.

[37] S. Chytiri, I. Chouliara, I. N. Savvaidis, and M. G. Kontominas, "Microbiological, chemical and sensory assessment of iced whole and filleted aquacultured rainbow trout," Food Microbiology, vol. 21, no. 2, pp. 157-165, 2004.

[38] U. Erikson, F. Shabani, E. Beli, S. Muji, and A. Rexhepi, "The impacts of perimortem stress and gutting on quality index and colour of rainbow trout (Oncorhynchus mykiss) during ice storage: a commercial case study," European Food Research and Technology, pp. 1-10, 2017.

[39] X. Liu, Y. Jiang, S. Shen, Y. Luo, and L. Gao, "Comparison of Arrhenius model and artificial neuronal network for the quality prediction of rainbow trout (Oncorhynchus mykiss) fillets during storage at different temperatures," LWT- Food Science and Technology, vol. 60, no. 1, pp. 142-147, 2015.

[40] A. Huidobro, A. Pastor, and M. Tejada, "Adenosine triphosphate and derivatives as freshness indicators of gilthead sea bream (Sparus aurata)," Food Science and Technology International, vol. 7, no. 1, pp. 23-30, 2001.

[41] P. Howgate, "A review of the kinetics of degradation of inosine monophosphate in some species of fish during chilled storage," International Journal of Food Science \& Technology, vol. 41, no. 4, pp. 341-353, 2006.

[42] P. Howgate, "Kinetics of degradation of adenosine triphosphate in chill-stored rainbow trout (Oncorhynchus mykiss)," International Journal of Food Science \& Technology, vol. 40, no. 6, pp. 579-588, 2005.

[43] H. H. Huss, "Fresh fish. Quality and Quality Change," in FAO Fisheries, Rome, 1988.

[44] S. Cakli, B. Kilinc, A. Cadun, T. Dincer, and S. Tolasa, "Effects of gutting and ungutting on microbiological, chemical, and sensory properties of aquacultured sea bream (Sparus aurata) and sea bass (Dicentrarchus labrax) stored in ice," Critical Reviews in Food Science and Nutrition, vol. 46, no. 7, pp. 519527, 2006.

[45] S. Cakli, B. Kilinc, A. Cadun, T. Dincer, and S. Tolasa, "Quality differences of whole ungutted sea bream (Sparus aurata) and sea bass (Dicentrarchus labrax) while stored in ice," Food Control, vol. 18, no. 5, pp. 391-397, 2007.

[46] V. P. Lougovois, E. R. Kyranas, and V. R. Kyrana, "Comparison of selected methods of assessing freshness quality and remaining storage life of iced gilthead sea bream (Sparus aurata)," Food Research International, vol. 36, no. 6, pp. 551-560, 2003.

[47] A. Gelman, R. Pasteur, and M. Rave, "Quality changes and storage life of common carp (Cyprinus carpio) at various storage temperatures," Journal of the Science of Food and Agriculture, vol. 52, no. 2, pp. 231-247, 1990.

[48] D. Agüeria, P. Sanzano, P. Vaz-Pires, E. Rodríguez, and M. I. Yeannes, "Development of Quality Index Method Scheme for Common Carp (Cyprinus carpio) Stored in Ice: Shelf-Life Assessment by Physicochemical, Microbiological, and Sensory Quality Indices," Journal of Aquatic Food Product Technology, vol. 25, no. 5, pp. 708-723, 2016.

[49] I. Icekson, R. Pasteur, V. Drabkin et al., "Prolonging shelf-life of carp by combined ionising radiation and refrigeration," Journal of the Science of Food and Agriculture, vol. 72, no. 3, pp. 353-358, 1996.

[50] L. S. Smith, "Digestion in Teleost Fishes," in Fish Feed Technology: Aquaculture Development and Coordination Programme,
Lectures presented at the FAO/UNDP Training Course in Fish Feed Technology, p. 400, Seattle, Wash, 1978.

[51] M. Ghanbari, W. Kneifel, and K. J. Domig, "A new view of the fish gut microbiome: advances from next-generation sequencing," Aquaculture, vol. 448, pp. 464-475, 2015.

[52] A. R. Desai, M. G. Links, S. A. Collins et al., "Effects of plantbased diets on the distal gut microbiome of rainbow trout (Oncorhynchus mykiss)," Aquaculture, vol. 350-353, pp. 134$142,2012$.

[53] H.-C. Ingerslev, M. L. Strube, L. V. G. Jørgensen, I. Dalsgaard, M. Boye, and L. Madsen, "Diet type dictates the gut microbiota and the immune response against Yersinia ruckeri in rainbow trout (Oncorhynchus mykiss)," Fish and Shellfish Immunology, vol. 40, no. 2, pp. 624-633, 2014. 


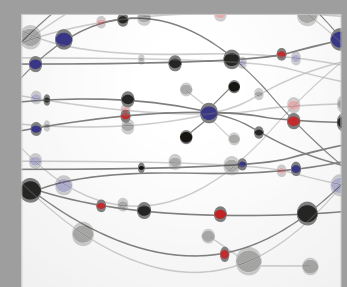

The Scientific World Journal
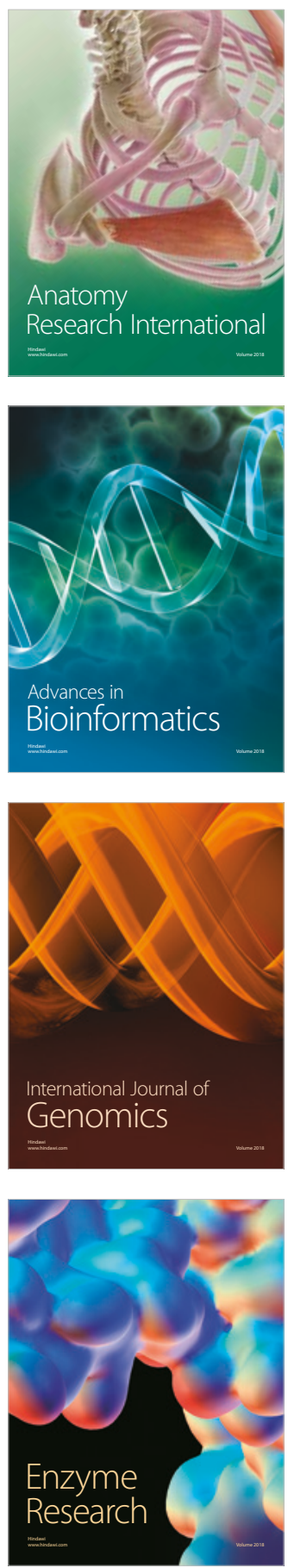
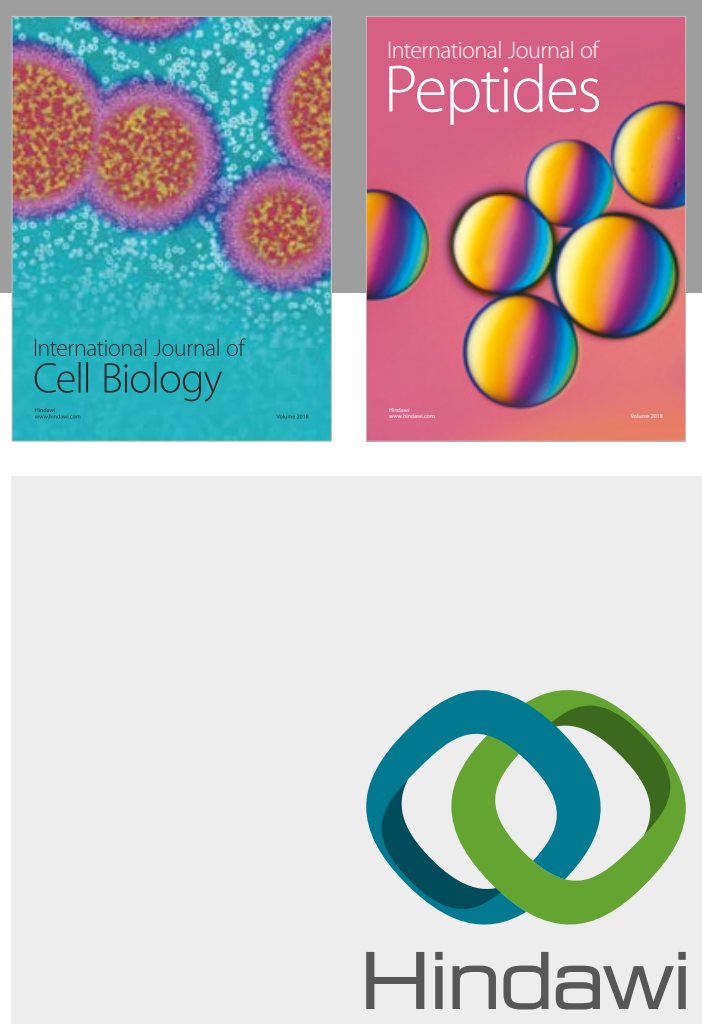

Submit your manuscripts at

www.hindawi.com
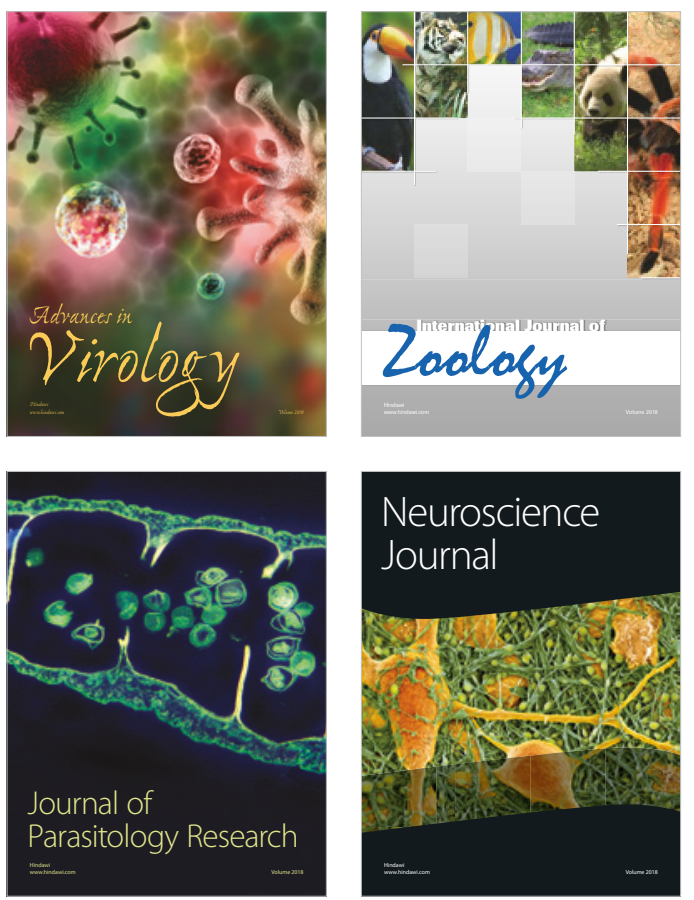
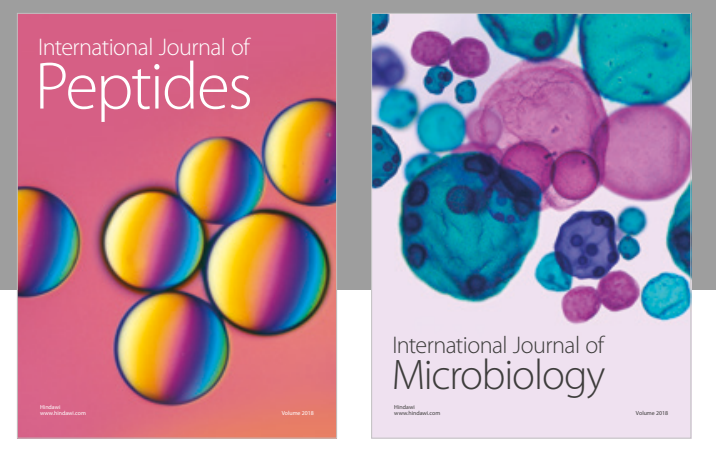

nternational Journal of Microbiology
Journal of
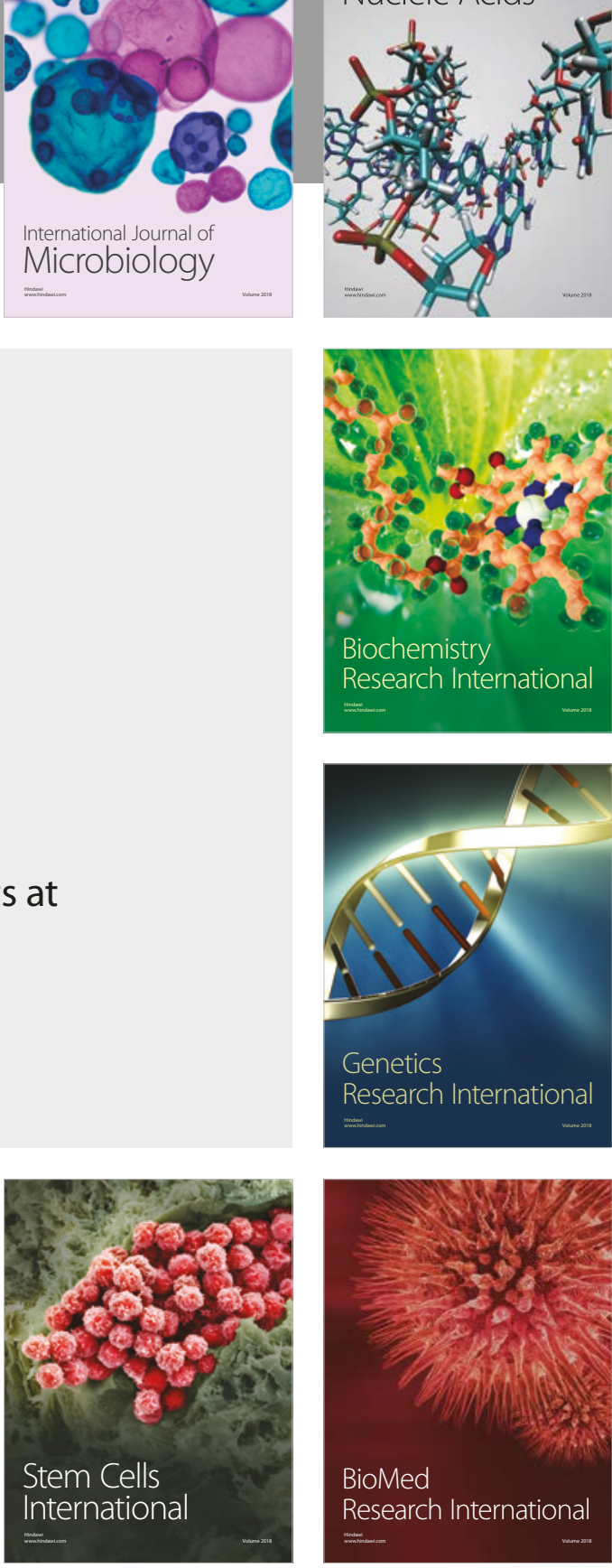
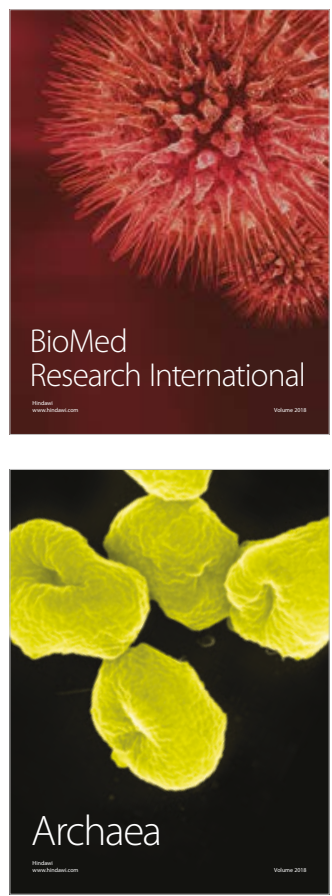